\title{
Electronic Cigarettes and Pregnancy - What Do We Currently Know?
}

\author{
Filip Niestony ${ }^{1}$, Dominik Niestony ${ }^{1}$, Hubert Mado ${ }^{2^{*}}$ (D)
}

${ }^{1}$ Faculty of Medical Sciences in Zabrze, Medical University of Silesia, Katowice, POLAND

${ }^{2}$ Department of Histology and Cell Pathology in Zabrze, Medical University of Silesia, Katowice, POLAND

*Corresponding Author: hubert.mado@med.sum.edu.pl

Citation: Niestony F, Niesłony D, Mado H. Electronic Cigarettes and Pregnancy - What Do We Currently Know?. Electron J Gen Med. 2022;19(1):em341. https://doi.org/10.29333/ejgm/11410

\section{ARTICLE INFO}

Received: 3 Sep. 2021

Accepted: 27 Oct. 2021

\begin{abstract}
Electronic cigarettes are relatively new devices. They were invented in 2003 with the aim of reducing the harm caused by cigarette smoking. Since their debut, they have achieved worldwide popularity, which continues to grow. The public believes that e-cigarettes are harmless or only slightly harmful. This leads to dangerous trends increased use of e- cigarettes by young people and pregnant women. Indeed, e-cigarette aerosol contains much lower concentrations of toxic and carcinogenic substances compared to traditional cigarettes. Furthermore, ecigarettes are a much safer option for most adults. However, this does not mean that they are entirely safe particularly for a group such as pregnant women. Electronic cigarettes deliver the same or even higher concentrations of nicotine as traditional cigarettes. However, the placental barrier is no obstacle to nicotine. There are many reports of its harmfulness to fetal development. Nicotine impairs the development of the respiratory, nervous, and cardiovascular systems, among others. In addition, the aerosol of electronic cigarettes has a significant number of additives, which are highly dependent on the manufacturer. As a result, we are unable to know all their side effects. Furthermore, despite reports of the harmfulness of e-cigarettes, it is still uncertain whether they are an effective method of quitting the smoking habit. There are some works which indicate a decrease in the effectiveness of attempts to stop using cigarettes. What is more, there are also those which demonstrate that the use of e-cigarettes can lead to dual use with traditional cigarettes. Given the current state of knowledge, pregnant women should not be advised to use e-cigarettes to stop smoking traditional ones. Certainly, the use of e-cigarettes during pregnancy should be strongly discouraged.
\end{abstract}

Keywords: electronic cigarettes, pregnancy, e-cigarettes, fecundability, smoking

\section{INTRODUCTION}

Electronic cigarettes (e-cigarettes) were invented by Hon Lik in 2003 with the aim of making cigarette smoking less harmful. The benefits were supposed to include the cessation or reduced frequency of smoking traditional cigarettes [1-3]. Unfortunately, their effectiveness in this matter is highly controversial. On the one hand, there are studies proving that nicotine replacement therapy using e-cigarettes guarantees a higher quit rate compared to standard therapy (18\% vs. $9.9 \%$ ) [3]. On the other hand, however, there are also studies showing a weak or even negative correlation between e-cigarette use and successful cessation of traditional cigarettes - smokers who use an e-cigarette for this purpose may be up to $28 \%$ less likely to succeed [4,5]. The popularity of e-cigarettes is successively increasing despite the fact that there is a significant lack of studies evaluating their harmfulness [6-9]. The public's belief that e-cigarettes are harmless or slightly harmful leads to dangerous trends, e.g., normalization of smoking and increased use of e-cigarettes among young people and pregnant women. Of the adolescents who use ecigarettes, a large proportion had no previous exposure to traditional cigarettes, and use of these devices increases the chances of starting to smoke tobacco cigarettes in the future and developing an addiction [1,3,8]. The intrinsically most likely negative impact of e-cigarettes should also not be overlooked [4]. Low awareness of the potential harmful effects of e-cigarettes on the fetus is also a problem [6].

Therefore, the aim of this work is to concisely discuss the topic of e-cigarette use in pregnancy.

\section{E-CIGARETTES VS. CIGARETTES}

The harm of e-cigarettes was originally estimated to be 20 times less than traditional cigarettes [10]. However, this value has not been documented anywhere [10]. The reduction in harmfulness supposedly results mainly from the fact that ecigarettes do not contain tobacco - there is no combustion process during smoking, which results in the lack of carbon monoxide and nitrosamines production [3]. E-cigarettes are also supposed to be associated with reduced exposure to benzene, PAHs (polycyclic aromatic hydrocarbons) and cadmium, among others $[3,4]$. However, this does not mean that e-cigarettes are free of toxic substances [1,11]. E-cigarette aerosol also contains substances found in analogue cigarette smoke, such as nicotine, ultra-fine particles, heavy metals and volatile organic compounds [12]. Nevertheless, it should be noted that these substances are found in aerosols in much smaller quantities and, moreover, their content depends 
largely on the manufacturer $[1,12]$. The products formed when heating glycol and glycerin, which are the basic ingredients of e-cigarettes, may cause allergy and irritate the respiratory tract [13]. In addition, when substances contained in e-cigarettes are heated, acrolein, acetaldehyde and formic aldehyde, inter alia, may be formed $[1,4]$. The e-cigarette is also composed of flavors that give it a characteristic taste - at the moment there are more than 7700 of them available [13]. The multitude of these substances makes it very difficult to identify their harmfulness. Many flavors, even those that are approved for consumption can be hazardous when inhaled [13]. An example of this is acetyl and diacetyl, which when inhaled can cause bronchiolitis [14]. The same is true for vitamin E acetate, inhalation of which can be associated with lung damage, ${ }^{3}$. Ecigarettes weaken the immune system and also have a negative effect on the circulatory and respiratory systems $[4,15]$. It has been proven that users experience weakened lung function, increased blood pressure, heart rate and increased arterial stiffness [4]. Even after a short period of e-cigarette use, airway resistance may increase and the concentration of nitric oxide in the exhaled air may decrease [4]. In asthmatics, smoking e-cigarettes can increase the symptoms of the disease $[4,13]$. This is due to increased inflammatory processes and oxidative stress damaging the airway epithelium ${ }^{3}$. It also increases susceptibility to viral infections - a person who uses e-cigarettes is up to 5 times more likely to contract COVID-19 (Coronavirus disease 2019) [1,16].

Given the growing popularity of e-cigarettes among youth and pregnant women and the fact that most e-cigarette users also use traditional cigarettes, it is hard to consider e-cigarettes only as a therapeutic option for smoking cessation, which they were originally intended to be $[1,3]$. Nevertheless, e-cigarettes seem to remain a lesser evil than analogue cigarettes for the time being [2]. However, evil, even lesser evil, is still evil, and this is something that everyone, especially pregnant women, should remember. Furthermore, the long-term effects of using e-cigarettes are currently unknown [17]. Moreover, the subject of e-cigarettes is rather poorly researched, so it is uncertain whether forms of EVALI (E-Cigarette or Vaping-Associated Lung Injury) of varying severity are not prevalent in the population of users of these devices [4]. Therefore, for the time being, we can only speak of the potential lower harmfulness of e-cigarettes.

\section{E-CIGARETTES AND FERTILITY}

There are very few studies evaluating the effects of ecigarette use on a woman's ability to become pregnant. It is known that the use of traditional cigarettes can cause reduced fertility by affecting hormone balance, altering folliculogenesis and reducing oocyte quantity and quality [18-21]. Similar mechanisms are likely to occur with e-cigarette smoking due to exposure to nicotine, heavy metals, flavors and other chemicals [12]. However, a reliable comparison of the harms of traditional and e-cigarette use is very difficult due to the fact that smoking both types of cigarettes is highly correlated [12]. The largest study to date $(n=4586)$ on the effect of e-cigarette use on maternal fertility found little reduction in fertility [12]. This association did not increase with increasing intensity of ecigarette use. It should be borne in mind that e-cigarette use was associated with lower education, income, healthy eating index, multivitamin use, higher body mass index, higher caffeine intake, marijuana use, diagnosed depression, number of partners and frequency of sexual intercourse, and the confidence intervals were wide so it is not entirely clear whether reduced fertility is causally related to e-cigarette use [12]. It seems that, given this state of knowledge, it should not be recommended for female smokers struggling with infertility to replace traditional cigarettes with e-cigarettes. In addition, men who are trying to have a child should also take into account that e-cigarettes can reduce the number of sperm cells [22].

\section{EFFECTS OF E-CIGARETTES ON PREGNANCY AND THE FETUS}

The e-cigarette aerosol contains much smaller amounts of almost all toxic and carcinogenic substances found in tobacco smoke $[12,17]$. The exception is nicotine, which is delivered to the body in the same or even greater amounts, and the placental barrier is not an obstacle to it $[2,6,23]$. Therefore, when analyzing the effects of e-cigarette use on the fetus, it is important to look closely at the effects of nicotine.

The impact of nicotine is reported in many animal studies. Firstly, they suggest reduced fertility. Secondly, in fetal matter they indicate an increased risk of obesity, hypertension, cardiovascular complications, peptic ulcer disease, gastric cancer, behavioral problems, ADHD (attention-deficit hyperactivity disorder) and reduced fetal lung development resulting in reduced FEF (forced expiratory flow) in the future $[1,8,24]$. In addition, short-term memory deficits have been demonstrated in the offspring of rats exposed to e-cigarette aerosol $[3,24]$. Effects of nicotine that are well known from both animal and human studies include increased risk of eclampsia, premature birth, stillbirth, reduced birth weight, reduced lung function at birth, apnea, cleft lip and palate $[1,6,8]$. Nicotine is also likely to adversely affect muscle and skeletal development of the newborn [1].

In addition to nicotine, a wide range of chemicals in the form of flavorings may be present in e-cigarettes. Non-nicotine effects have been shown to include hyperreactivity in the offspring of rats exposed to e-cigarette aerosol [3,24]. Furthermore, animal studies revealed that e-cigarettes cause abnormal inflammation in maternal and fetal lungs regardless of nicotine content. Moreover, these alterations can be observed in the offspring of smokers in adulthood [25].

Smoking may also affect the epigenetics of offspring [2426]. These effects include abnormal, increased DNA methylation. Studies show that these effects appear to be independent of nicotine and others link them to an increased chance of lung disease (e.g., asthma) in the future [25,27].

It is worth remembering that gametogenesis in women occurs during fetal life. Therefore, a pregnant woman who smokes endangers not only her own children but also the offspring of her daughters. And indeed, a study on rats showed an increase in the incidence of asthma in the second generation [28].

In cases where quitting smoking is unlikely due to severe addiction, additional vitamin C supplementation $(500 \mathrm{mg} / \mathrm{d}$ ) may be beneficial. Studies have shown that it blocks some of the intrauterine effects of nicotine leading to improved neonatal PFT (Pulmonary Functional Tests) scores and a lower chance of wheezing in the first year of life [29,30]. Additionally, it prevents changes in DNA methylation caused by smoking, resulting in a lower chance of developing asthma in the future 


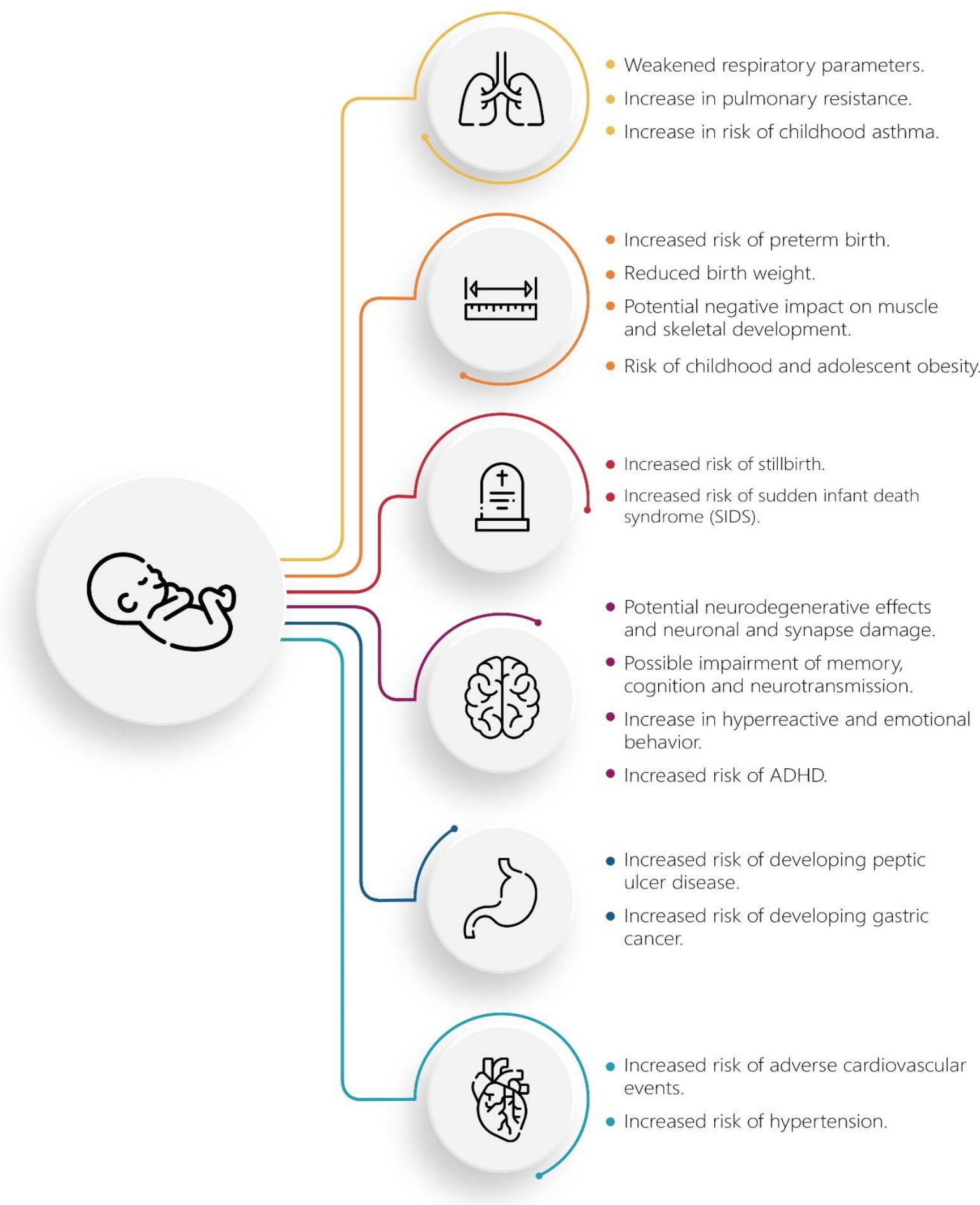

Figure 1. Effects of e-cigarette use during pregnancy on the fetus

[31,32]. The potential benefits would apply to both traditional and e-cigarette smokers, but it is important to remember that quitting smoking should remain the priority [15].

Studying the effects of e-cigarette smoking on the fetus is very hard. It is hard to assess the real impact on a human fetus, so most studies draw conclusions based on animal models. This may skew the strength of the evidence, but at this point we do not have more favorable alternatives. At present, therefore, most studies point to potentially harmful effects of e-cigarette smoking on pregnancy, the fetus and ultimately the born child. A summary of the adverse effects on the fetus from e-cigarette use during pregnancy is shown in Figure 1.

\section{WHY DO PREGNANT WOMEN SMOKE E- CIGARETTES}

To answer this question, one must first look at the problem of tobacco cigarettes. Their high harmfulness is scientifically proven. They are the most common cause of preventable infant death and morbidity [33]. Cigarette smoking is associated, among other things, with a neonatal weight deficit of 100 to $300 \mathrm{~g}$, low birth weight (i.e., less than $2500 \mathrm{~g}$ ), $13-19 \%$ of preterm births with low birth weight, $23-34 \%$ of cases of sudden cot death syndrome, $5-7 \%$ of deaths of preterm infants, a $46 \%$ 
increase in the risk of miscarriage, a $33 \%$ increase in the risk of perinatal death and a $22 \%$ increase in the risk of neonatal death [34]. The overall negative impact on the offspring is well known, so women are highly motivated to quit [33]. Proportionately more women give up cigarettes during pregnancy than at any other time in their lives. Indeed, 12-53\% of women who smoked before pregnancy spontaneously quit before their first visit to the gynecologist [33].

The situation is different with e-cigarettes. Although many scientific papers point to their potentially harmful effects on offspring, there is a public perception that e-cigarettes are much less harmful than conventional smoking and even that it is safe to use them [35]. They are the most commonly chosen cessation aid despite not being officially approved as a treatment for addiction [3]. Researchers postulate that ecigarette use, due to its less negative perception in society, is met with less stigma [27]. These effects have made the use of ecigarettes during pregnancy a common phenomenon. Studies have shown that at least as many women use them as traditional cigarettes (5.62\% of pregnant women used tobacco cigarettes, $6.52 \%$ used e-cigarettes and $8.54 \%$ of pregnant women were dual users) [36].

\section{CONCLUSIONS}

Analysis of the impact of e-cigarettes on offspring requires a distinction between theory and practice. In theory, they could have a positive impact by helping people to stop smoking altogether or reducing harm by switching from combustible cigarettes to e-cigarettes. This is due to research that suggests they are potentially (and just potentially) less harmful. In practice, however, they may reduce the proportion of women who completely quit smoking during pregnancy in favor of using e-cigarettes. Additionally, as they do not show a clear correlation with quitting, they may lead to dual use ( $75 \%$ of ecigarette users also smoke conventional cigarettes) which paradoxically may increase nicotine exposure. In some cases, e-cigarettes may pose dangerous health effects that do not occur with tobacco cigarettes or even exceed them. Additional human studies are needed to better understand the health effects that e-cigarettes have on offspring. Considering all the facts gathered in this paper, e-cigarettes should not be recommended to pregnant women for smoking cessation. Furthermore, it seems reasonable to strongly discourage any use of e-cigarettes during pregnancy due to strong indications of their harm to pregnancy and the fetus.

Author contributions: All authors have sufficiently contributed to the study, and agreed with the results and conclusions.

Funding: No funding source is reported for this study.

Declaration of interest: No conflict of interest is declared by authors.

\section{REFERENCES}

1. Carlsen KCL, Skjerven HO, Carlsen KH. The toxicity of Ecigarettes and children's respiratory health. Paediatr Respir Rev 2018;28:63-7. https://doi.org/10.1016/ j.prrv.2018.01.002 PMid:29580719

2. Peterson LA, Hecht SS. Tobacco, e-cigarettes, and child health. Curr Opin Pediatr 2017;29:225-30. https://doi.org/10.1097/MOP.0000000000000456 PMid:28059903 PMCid:PMC5598780
3. Ruszkiewicz JA, Zhang Z, Gonçalves FM, Tizabi Y, Zelikoff JT, Aschner M. Neurotoxicity of e-cigarettes. Food Chem Toxicol;138:111245. https://doi.org/10.1016/j.fct.2020. 111245 PMid:32145355 PMCid:PMC7089837

4. Mado H, Reichman-Warmusz E, Wojnicz R. The vaping product use associated lung injury: is this a new pulmonary disease entity? Rev Environ Health 2021;36:145-57. https://doi.org/10.1515/reveh-2020-0076

5. Chiang SC, Abroms LC, Cleary SD, Pant I, Doherty L, Krishnan N. E-cigarettes and smoking cessation: a prospective study of a national sample of pregnant smokers. BMC Public Health 2019;19:964. https://doi.org/10.1186/s12889-019-7299-7 PMid:31319846 PMCid:PMC6637539

6. Whittington JR, Simmons PM, Phillips AM, Gammill SK, et al. The use of electronic cigarettes in pregnancy: A review of the Lliterature. Obstet Gynecol Surv 2018;73:544-9. https://doi.org/10.1097/OGX.0000000000000595 PMid:30265741

7. Breland A, Soule E, Lopez A, et al. Electronic cigarettes: what are they and what do they do? Ann N Y Acad Sci 2017;1394:5-30. https://doi.org/10.1111/nyas.12977 PMid: 26774031 PMCid:PMC4947026

8. Spindel ER, McEvoy CT. The role of nicotine in the effects of maternal smoking during pregnancy on lung development and childhood respiratory disease. Implications for dangers of e-cigarettes. Am J Respir Crit Care Med 2016;193:486-94. https://doi.org/10.1164/rccm.2015102013PP PMid:26756937 PMCid:PMC4824926

9. Hawkins SS, Wylie BJ, Hacker MR. Use of ENDS and cigarettes during pregnancy. Am J Prev Med 2020;58:122-8. https://doi.org/10.1016/j.amepre.2019.08.031 PMid:31862099

10. Nicotine without smoke: Tobacco harm reduction / RCP London. 2016. Available at: https://www.rcplondon.ac.uk/ projects/outputs/nicotine-without-smoke-tobacco-harmreduction (Accessed: 29 August 2021).

11. Schilling L, Spallek J, Maul H, et al. Active and passive exposure to tobacco and e-cigarettes during pregnancy. Matern Child Health J 2021;25:656. https://doi.org/10.1007 /s10995-020-03037-8 PMid:33211261 PMCid:PMC8032614

12. Harlow AF, Hatch EE, Wesselink AK, Rothman KJ, Wise LA. Electronic cigarettes and fecundability: Results from a prospective preconception cohort study. Am J Epidemiol 2021;190:353-61. https://doi.org/10.1093/aje/kwaa067 PMid:32378702 PMCid:PMC8086241

13. Oncken C, Ricci KA, Kuo CL, Dornelas E, Kranzler HR, Sankey $\mathrm{HZ}$. Correlates of electronic cigarettes use before and during pregnancy. Nicotine Tob Res 2017;19:585-90. https://doi.org/10.1093/ntr/ntw225 PMid:28403454 PMCid: PMC5896457

14. Cherian S V., Kumar A, Estrada-Y-Martin RM. E-Cigarette or Vaping Product-Associated Lung Injury: A Review. Am J Med 2020;133:657-63. https://doi.org/10.1016/j.amjmed.2020. 02.004 PMid:32179055

15. Spindel ER, McEvoy CT. The role of nicotine in the effects of maternal smoking during pregnancy on lung development and childhood respiratory disease. Implications for dangers of e-cigarettes. Am J Respir Crit Care Med 2016;193:486-94. https://doi.org/10.1164/rccm.2015102013PP PMid:26756937 PMCid:PMC4824926 
16. Gaiha SM, Cheng J, Halpern-Felsher B. Association between youth smoking, electronic cigarette use, and COVID-19. J Adolesc Health 2020;67:519-23. https://doi.org/10.1016/j.ja dohealth.2020.07.002 PMid:32798097 PMCid:PMC7417895

17. Tegin G, Mekala HM, Sarai SK, Lippman S. E-cigarette toxicity? South Med J 2018;111:35-8. https://doi.org/ 10.14423/SMJ.0000000000000749 PMid:29298367

18. Windham GC, Mitchell $P$, Anderson $M$, et al. Cigarette smoking and effects on hormone function in premenopausal women. Environ Health Perspect 2005;113:1285-90. https://doi.org/10.1289/ehp.7899 PMid: 16203235 PMCid:PMC1281267

19. Budani MC, Tiboni GM. Ovotoxicity of cigarette smoke: A systematic review of the literature. Reprod Toxicol 2017;72:164-81. https://doi.org/10.1016/j.reprotox.2017.06 .184 PMid:28684319

20. Sharara FJ, Beatse SN, Leonardi MR, et al. Cigarette smoking accelerates the development of diminished ovarian reserve as evidenced by the clomiphene citrate challenge test. Fertil Steril 1994;62:257-62. https://doi.org/10.1016/S0015-0282(16)56875-7

21. Zenzes MT, Reed TE, Casper RF. Effects of cigarette smoking and age on the maturation of human oocytes. Hum Reprod 1997;12:1736-41. https://doi.org/10.1093/humrep/12.8. 1736 PMid:9308804

22. Holmboe SA, Priskorn L, Jensen TK, et al. Use of ecigarettes associated with lower sperm counts in a crosssectional study of young men from the general population. Hum Reprod 2020;35:1693-701. https://doi.org/10.1093/ humrep/deaa089 PMid:32558890

23. Talih S, Balhas Z, Eissenberg T, et al. Effects of user puff topography, device voltage, and liquid nicotine concentration on electronic cigarette nicotine yield: Measurements and model predictions. Nicotine Tob Res 2015;17:150-7. https://doi.org/10.1093/ntr/ntu174 PMid: 25187061 PMCid:PMC4837998

24. Sailer S, Sebastiani G, Andreu-Férnández V, García-Algar O. Impact of nicotine replacement and electronic nicotine delivery systems on fetal brain development. Int J Environ Res Public Health 2019;16(24):5113. https://doi.org/10. 3390/ijerph16245113 PMid:31847348 PMCid:PMC6950274

25. Chen H, Li G, Chan YL, et al. Maternal e-cigarette exposure in mice alters DNA methylation and lung cytokine expression in offspring. Am J Respir Cell Mol Biol 2018;58:366-77. https://doi.org/10.1165/rcmb.20170206RC PMid:28960086

26. Nguyen T, Li GE, Chen $\mathrm{H}$, et al. Maternal e-cigarette exposure results in cognitive and epigenetic alterations in offspring in a mouse model. Chem Res Toxicol 2018;31:60111. https://doi.org/10.1021/acs.chemrestox.8b00084 PMid: 29863869
27. Suter MA, Mastrobattista J, Sachs M, et al. Is there evidence for potential harm of electronic cigarette use in pregnancy? Birth Defects Res A Clin Mol Teratol 2015;103:186. https://doi.org/10.1002/bdra.23333 PMid:25366492 PMCid: PMC4830434

28. Rehan VK, Liu J, Naeem E, Tian J, et al. Perinatal nicotine exposure induces asthma in second generation offspring. BMC Med 2012;10:129. https://doi.org/10.1186/1741-701510-129 PMid:23106849 PMCid:PMC3568737

29. McEvoy CT, Schilling D, Clay N, et al. Vitamin C Supplementation for Pregnant Smoking Women and Pulmonary Function in Their Newborn Infants: A Randomized Clinical Trial. JAMA 2014;311:2074-82. https://doi.org/10.1001/jama.2014.5217 PMid:24838476 PMCid:PMC4296045

30. McEvoy CT, Shorey-Kendrick LE, Milner K, Schilling D, et al. Oral vitamin C (500 mg/d) to pregnant smokers improves infant airway function at 3 months (VCSIP). A randomized trial. Am J Respir Crit Care Med 2019;199:1139-47. https://doi.org/10.1164/rccm.201805-10110C PMid:30522343 PMCid:PMC6515875

31. Shorey-Kendrick LE, McEvoy CT, Ferguson B, Burchard J, et al. Vitamin C prevents offspring DNA methylation changes associated with maternal smoking in pregnancy. Am J Respir Crit Care Med 2017;196:745-55. https://doi.org/ 10.1164/rccm.201610-21410C PMid:28422514 PMCid: PMC5620677

32. Yieh L, McEvoy CT, Hoffman SW, Caughey AB, et al. Cost effectiveness of vitamin c supplementation for pregnant smokers to improve offspring lung function at birth and reduce childhood wheeze/asthma. J Perinatol 2018;38:8207. https://doi.org/10.1038/s41372-018-0135-6 PMid: 29785060 PMCid:PMC6414472

33. Crume T. Tobacco use during pregnancy. Clin Obstet Gynecol 2019;62:128-41. https://doi.org/10.1097/ GRF.0000000000000413 PMid:30668557

34. loakeimidis N, Vlachopoulos C, Katsi V, Tousoulis D. Smoking cessation strategies in pregnancy: Current concepts and controversies. Hellenic J Cardiol 2019;60:115. https://doi.org/10.1016/j.hjc.2018.09.001 PMid:30296484 35. Anand V, McGinty KL, O'Brien K, et al. E-cigarette use and beliefs among urban public high school students in North Carolina. J Adolesc Heal 2015;57:46-51. https://doi.org/ 10.1016/j.jadohealth.2015.03.018 PMid:26095408

36. Wagner NJ, Camerota M, Propper C. Prevalence and perceptions of electronic cigarette use during pregnancy. Matern Child Heal J 2017;21(8):1655-61. https://doi.org/10.1007/s10995-016-2257-9 PMid:28084577 PMCid:PMC5509528 